\title{
ABORTAMOS. EXPERIENCIAS AFECTIVAS ENTRE LOS DISCURSOS Y LOS CUERPOS
}

Sobre Dahiana Belfiori. Código Rosa. Relatos sobre abortos. Córdoba: La Parte Maldita, 2014, 144 pp.

Rosana Guardalá

UNR

El libro de Belfiori comienza con dos enunciados fundamentales: una dedicatoria ("A todas las que abortamos y abortaremos") que conjuga en sus núcleos un nosotras presente y futuro. El otro enunciado es el prólogo de la escritora entrerriana, Selva Almada, con el que se abre la multiplicidad (relatos) que se cifra ya en el título del libro. Almada recupera en una edad, una hora, un tiempo y espacio: "Cuando tenía trece años, en la hora de biología vimos una película, 'El grito silencioso' (...)” (p. 9), su primer relato sobre el aborto. Un médico antiabortista converso que muestra cómo un feto "supuestamente sufre, padece, tratando de escaparle a la muerte". Este relato aloja una intuición que el film intenta documentar: "hasta el momento, para mí, la palabra aborto (...) sin saber exactamente el significado, se intuye. Abortar era algo terrible. Abortar era ofender a dios" (p. 9). Muchas mujeres crecimos bajo y en este discurso: aborto-pecado-asesinato.

Selva Almada nos comparte el tránsito de la duda a la claridad en su experiencia: "Todavía la moral católica y la educación patriarcal no me permitían comprender que una mujer tiene derecho a decidir sobre su cuerpo y sobre todo lo 
que ocurra en él y con él (...)". Las anécdotas que se hacen necesarias para entender pero también para sentir cercanas esas experiencias, saber que abortar no es un delito ni un trauma, que existe un método y un modo de decidir que es individual pero que se transita colectivamente desde la razón así como también desde el afecto.

Desde la perspectiva anterior, Código Rosa. Relatos sobre abortos, despliega esa lectura en diecisiete relatos que cuentan que abortar es un hecho, una decisión que nos permite pensarnos como subjetividades particulares con deseos y vidas singulares. Este libro es una invitación a conocer diferentes historias, comprender el aborto ya no como un tabú sino como una posibilidad, como decisión sobre nuestro propio cuerpo.

Dahiana Belfiori, activista feminista, poeta y narradora es quien escribe y ordena estos relatos, partiendo de una pregunta: ¿Por qué Código Rosa?: “(...) una especie de código mínimo que regulariza aquello que sigue estando fuera de la ley, prácticas de las que las integrantes del Colectivo Rosa informan corriéndose de la idea de simples 'pasadoras de datos' para convertirse en sujetas activas" (p. 13).

Este libro tiene su germen escriturario en más de veinte entrevistas que se realizaron entre el 2012 y el 2013 a mujeres que abortaron con misoprostol en la provincia de Neuquén. Sin duda esta decisión política de Las Revueltas, integrantes que conforman el Colectivo Feminista La Revuelta hace posible la escritura por parte de Dahiana Belfiori, que resuelve posible tensiones entre lo público, lo privado y lo íntimo. Si bien el testimonio es personal e individual, la escritura lo vuelve colectivo y compartido a los fines de ser difundido "para que ayude a otras". Allí las fronteras entre lo íntimo y lo privado se difuminan para poner las palabras testimoniales al servicio de otras mujeres. Porque como deja traslucir la dedicatoria y 
sostiene cada una de estas páginas: puede que la práctica se produzca en un cuerpo pero abortamos todas, las que acompañan, las que escuchan, las que asisten. Las mujeres hacemos del vínculo, una práctica. De allí que sea importante destacar la calidad de los testimonios, la voluntad de las entrevistadas. Cabe aclarar aquí que los relatos tienen como base las experiencias de mujeres heterosexuales, si bien "los abortos ocurren en cuerpos de lesbianas, trans y bisexuales", porque son ellas las que accedieron a colaborar.

Belfiori reconoce que hace más de diez años Rima (Red Infomativa de Mujeres de Argentina) lanzó una serie de experiencia bajo el nombre "Yo aborté". No obstante, el paso del tiempo permitió y posibilitó un tono diferente. En ese momento abortar marcaba un antes y un después. Los relatos que aquí se reúnen muestran que abortar "es una cosa más". Es parte de la vida y una parte decisiva porque se elige a conciencia qué hacer con nuestro cuerpo.

Me detendré aquí en algunos de los diecisiete relatos que conforman el libro y que son un claro muestreo de la importancia y de la potencia de esta publicación. Gran parte de los títulos se desprenden de los mismos relatos. Ello conlleva a una lectura inevitable: los textos, los títulos, los dibujos que los acompañan conforman un todo que se sostiene y se amalgama en la experiencia. Recupero aquí una cuestión teórica que Vacarezza explícita en una suerte de epílogo: la experiencia tiene una dimensión social que se corre de la individual para convertirse en producción social. Este libro logra sumergirnos mediante la ficcionalización en la complejidad y la opacidad de una experiencia que ya no es vista como un objeto dado sino que se asume la constitución de una experiencia que es discursiva y que no se encuentra "confinada a un orden fijo de significados", como plantea Joan W. Scott. La experiencia del 
"yo aborte", "yo lo viví", sale del terreno individual para impulsar el debate legislativo estancado.

Estos relatos ficcionalizados, atravesados por imágenes, por las palabras de otrxs, nos recuerdan que no hay palabra primera ni palabra única. Toda palabra es una palabra atravesada y así lo deja ver con cuidadosa prosa la escritura de Dahiana Belfiori cuando inaugura el libro con un relato que se titula "No te quiero". Una mujer que habla con deseos, con preceptos, con toda una cultura. La omisión de un pronombre (yo) que potencia un deseo: no querer, a su vez querer, otra cosa. Una posibilidad: desear, amar, decidir. "Es hermoso sentir su piel. Es otro modo de hacer silencio". La prosa de Belfiori no tiene necesidad de resignar poesía por testimonio porque sabe que vivir es también, hacerse de palabras, afinar la mirada para decir mejor y decir mejor es encontrar la poesía en las cosas. Este libro es un tejido fuerte de voces como anuncia el final del primer relato: "Aquel encuentro en la plaza frente al monumento, con un grupo de mujeres hablando (...) me di cuenta que ellas hacen lo mismo que hago yo: acompañan a otras mujeres" (p. 23).

Abortar es una práctica, una situación compartida. Como bien dice otro de los relatos "Toda decisión es un contexto. Todo aborto también" (p. 41). Se aborta porque no se desea tener un bebé, porque no se desea ahora, porque no se tiene trabajo, lugar para vivir, porque es "otra boca para alimentar". Querer, pensar, desear desembocan de algún modo en una idea: proyectar. La maternidad no como una imposición que legitima la feminidad sino como un proyecto, entre otros. Preguntas en consonancia, abren otro relato: " $¿$ Parir nos hace ser madres? ¿Ser madres nos hace ser mujeres? ¿Qué significa ser mujer?" (p. 77). 
"¿A favor de qué vida estás?" toma su nombre de la contestación de Sonia al médico cuando éste le dice: "Mirá querida yo estoy a favor de la vida. No te puedo ayudar. Tenelo y lo das en adopción" (p. 82). El discurso médico en línea con la ley pero también con la moral en tanto Sonia ha sido infiel. Sin embargo, en su no poder, el ginecólogo le pasa otro dato. Una página en internet: la revuelta. Una denominación que define a un grupo de mujeres que activan. Un grupo que lejos de toda presunción semántica, tranquiliza, calma y acompaña. Tal vez por eso, después de abortar en su casa, acompañada, Sonia piensa que "Todas las mujeres deberían hacerse esta pregunta: 'Si algún día me pasa, ¿qué hago?' Lo tenés, no lo tenés. Yo siempre dije: no lo voy a tener. No es mi momento. ¿Por qué tengo que tener algo que no quiero?” (p. 83). En el "deberían” se esconde más que una indicación, un plural inclusivo, un derecho. Todas deberíamos detenernos y pensarlo para poder decidir.

Sin duda, este es un libro necesario en tanto, como bien señala Vacarezza, además de intervenir en los modos en que socialmente podemos ponerle palabras e incluso, pensar e imaginar el aborto, Código Rosa... y el socorrismo se comprometen en una tarea ambiciosa y urgente: la producción de saberes menos abstractos, encarnados y situados sobre el aborto. Código Rosa. Relatos sobre abortos de Dahiana Belfiori se presenta como un conjunto de escrituras que nos propone ser más conscientes, más valientes, más libres. Este libro viene a denunciar mediante las voces de las protagonistas un escenario social injusto y a reclamar un porvenir en el que el aborto legal, seguro y gratuito sea un hecho. 